\title{
THE PROGRAM OF MEDICAL AND PSYCHOLOGICAL SUPPORT OF THE PROCESS OF MEDICAL COLLEGE STUDENTS ADAPTATION TO WORK IN PRIMARY POSITIONS
}

\author{
Grishnyaeva O.V. https://orcid.org/0000-0001-6704-8541 \\ Kharkiv National Medical University, Kharkiv, Ukraine \\ elena1969lena1969@gmail.com
}

\begin{abstract}
Relevance. The current period of Ukraine development is characterized by a number of socially conditioned stressors, which result in a significant increase in the number of cases of short-term, and most often, long-term stress. In particular, the duration of verbal and non-verbal communication with patients, their relatives, junior nurses (nurses, paramedics, midwives) is longer than in doctors, thus the psychological stress, which is also associated with maintaining their physical health, is much greater. The consequence of this is professional exhaustion, development of psychosomatic pathology, change of place of work.

Objective of the work was to compile and propose a program of medical and psychological support for the process of medical college students adaptation to primary positions in treatment and prevention facilities.

Methods. Students of the Kharkiv Regional Medical College and the Dnipro Basic Medical College took part in the study. The experimental group consisted of students in the number of 100 people aged $17.5 \pm 1.5$ years. The control group ( $\mathrm{n}=45$ ) consisted of individuals $16.5 \pm 2.5$. The research was conducted without gender. To assess the tasks Author's questionnaires were used: «Means of adaptation of students to study in a medical university of I-III levels of accreditation», and individually - typological questionnaire LM Sobchik. The data validity test for the Individual Typological Questionnaire was conducted to determine the validity and reliability of the answers in the categories «False» and «Aggravation». Statistical methods were used: middle and outward correlation analysis according to the criteria of Spirman and Pirson, Student's criterion.

Results. The importance of medical and psychological support of the process of adaptation of junior medical specialists was studied, an original program was developed, which is an integrated structural procedural model of adaptation of medical college students to primary positions. After the introduction of the correctional program for working with students, the average level of student motivation increased by $17 \%$, which was confirmed by the data of statistical analysis before and after the experiment. The results were also obtained: the average level of students' adaptive capabilities increased by 2 times.

Conclusions. The program introduced into the educational process will allow for a short period of time to adapt them to work in primary positions, form the need for continuous education and adherence to the principles of a healthy lifestyle. It will allow you to consolidate a positive coping strategy not only in a work environment, but also in everyday life.
\end{abstract}

Keywords: medical-psychological support, adaptation, students, primary position, coping- behavior.

Relevance. The current period of Ukraine's development is characterized by a number of socially conditioned stressors, which result in a significant increase in cases of short-term, and most often, long-term stress. Military events, COVID-19 give medical personnel an additional reason to worry about their physical and psychological condition.

The duration of verbal and non-verbal communication with patients, their relatives, junior nurses (nurses, paramedics, midwives) is longer than in doctors, thus the psychological stress, which is also associated with maintaining their physical health, is much greater. Very often powerful emotional outbursts or emotional exhaustion can be traced. All this leads to persistent anxiety, stress and, as a consequence, psychosomatization and even the desire to change jobs, possibly the direction of professional activity.

From the perspective of medical management, there is one more problem in the work and social attitude to this category of specialists - material and moral satisfaction and public recognition of the importance of the work of nurses, paramedics and midwives.

It would be possible to simplify this problem by increasing wages (material motivation), but this is a tempo- rary measure which will not solve the problem, because the absence of certain individual-typological features of the subject in the presence of a stress factor does not allow to qualitatively master professional skills and perform them, especially in difficult critical conditions [1].

In psychology, the term "adaptation" refers to restructuring of the individual's psyche under the influence of objective environmental factors, as well as the ability of man to adapt to different environmental requirements without feeling internal discomfort and without conflict with the environment. Shafazhinskaya NE revealed the procedural side of the phenomenon of adaptation in contrast to the adaptation of animals, adaptation as a process of formation of certain, professional, personality traits.

Within the sociological approach, "adaptation" was identified as "socialization", so the problem of compliance with the forms of individual behavior, the basic rules and requirements for the performance of social functions. The sociological approach interprets adaptation as a process of "entry" of the individual into new social roles, and the essence of this process is a meaningful, creative adaptation of the individual to the conditions of life. In this context, psychocorrection of personality maladaptation can be used the concept of psychosynthesis 
by R. Assadjola. At the same time there is achievement of harmonious internal integration, comprehension of the true "I" and formation of the correct relations with other people [2].

In the theory of evolutionary development of living beings and substantiation of physiological adaptation I.P. Pavlov noted that the psychological state of man, his «heavy feelings» arising in the course of various adaptive processes when changing the usual way of life, when terminating normal activities, when losing loved ones, not to mention mental crises and breaking beliefs, have their physiological basis [3]. A detailed analysis of the concept of «adaptation» is given in the work of Konstantinov V.V. [4].

Very often when talking about adaptation to work, we do not pay attention to the general adaptation to daily changes in personal and social life during which a person is behind the walls of his workplace.

This fact is very important and we must understand that the same applies to impaired adaptation. The inability to relax and change social roles also leads to maladaptation. We can observe various negative emotions - from dissatisfaction to depression, which in the end will lead to a situation that a person will not be able to effectively adapt to work or, being already trained by a specialist to change jobs. To prepare a new specialist, you need to spend an average of 6 to 12 months.

The structure of the adaptation process has several components:

1. Psychophysiological stage, which includes the regime and rhythm of working hours, working conditions and the state of the workplace, physical and psychological stress.

2. Social stage: the organizational structure of the company, including traditions and norms of behavior and as a consequence - the relationship in the team.

3. Stage of professional realization: realization of professional skills and abilities, advanced training, application of criteria for evaluation of work results and temporary responsibilities.

4. Organizational stage: the status and value of the position they hold. The importance of the unit in which a person works, or will work.

Adaptation can be seen as a technique or task that aims to effectively attract a new employee to the company. As for students, in a short time we have the opportunity to train a qualified specialist, as well as to develop or develop personal qualities that would help this person feel confident in the workplace. In solving the problem of adaptation, first of all, the author of the article proposes to change the system of selection of future students of medical schools at the initial stage, using diagnostic methods of medical psychology. These studies should be aimed at the rapid identification of individual-typological features of personality, which will allow you to quickly adapt to the peculiarities of training and work in the medical field.
For the formation or greater development of innate useful skills it is necessary on the personal example of the teaching staff of a medical institution throughout the educational process to form and educate the personal qualities of students that are characteristic of the medical profession.

All these features of the educational process contribute to the effective adaptation of the medical student to work in the primary position in the treatment and prevention institution [6-10].

The objective of the work was to compile and propose a program of medical and psychological support for the process of adaptation of medical college students to primary positions in treatment and prevention facilities (PHC).

Task:

1. Analyze the cause of maladaptation.

2. On the basis of the conducted researches to make a technique of correction of maladaptation.

3. Evaluate the results of the implemented methodology.

Hypothesis: introduction into the educational process of a comprehensive correctional program of medical and psychological support of the adaptation process of medical college students will allow in a short period of time to adapt them to work in primary positions, will form the need for continuing education and healthy living. The process of psychoeducation will become an important part of their professional responsibilities.

\section{METHODS}

Students of the Kharkiv Regional Medical College and the Dnipro Basic Medical College took part in the study. The experimental group consisted of students in the number of 100 people aged $17.5 \pm 1.5$ years. The control group consisted of individuals $n=45 \quad 16.5 \pm 2.5$. The samples can be considered representative, they reflect the situation with age, gender, level of education. The research was conducted without gender.

To assess the tasks were used:

Author's questionnaires were used for the initial assessment of the motive for choosing the profession of a medical worker and to identify individual psychological features of the personality: «Means of adaptation of students to study in a medical university of I-III levels of accreditation», and individually - typological questionnaire LM Sobchik [11]. The data validity test for the Individual Typological Questionnaire was conducted to determine the validity and reliability of the answers in the categories «False» and «Aggravation».

Based on the methods: system approach, content analysis and concept analysis, the importance of medical and psychological support of the process of adaptation of junior medical specialists was studied, an original program was developed, which is an integrated structural procedural model of adaptation of medical college students to primary positions. 
These studies will help to correctly arrange personnel and prevent professional burnout of employees, which will save time and material costs for the search and training of new personnel.

The results of the preliminaries on the basis of foreign statistical methods: middle and outward correlation analysis according to the criteria of Spirman and Pirson, Student's criterion.

\section{RESULTS AND DISCUSSION}

Indications for medical and psychological correction may be: the presence of difficulties in the process of adaptation to study in a medical institution and adaptation to a primary position in a medical institution, informed consent to psychodiagnosis and psychological intervention, manifestations of psychological maladaptation and the need for psychiatric intervention (medical psychologist). Thus, the purpose of the correctional program is to determine the possibilities of adaptation and specialization of the future medical worker before starting his work in the primary position in the treatment and prevention facility

Task:

- study of the motive for which the profession of medical worker was chosen and to establish compliance with the possibility and degree of adaptation of respondents to the chosen profession

- normalization of psycho-emotional state and formation of skills of its self-regulation;

- awareness of the role of personalities for the formation of positive adaptation to primary positions;

- harmonization of personal characteristics through the formation of positive coping strategies.
Based on this, the developed program consists of successive stages (table 1).

The first stage contains three components: informative, motivational, forming an alliance of the doctor-psychologist and client. Neurolinguistic programming methods are effective.

The second stage of the psychocorrection program consisted of 2 parts: differentiated and general psychocorrection. Differentiated approach was used to clarify the causes of maladaptation and selection of tactics and methods that stabilize the psycho-emotional state of man and the correction of personalities. After the first part, general psychocorrection is used. We offer methods of psychosynthesis [2], neurolinguistic programming [3], fairy tale therapy [4], arrangement by the method of Bert Hellinger [5]. Due to the fact that they are aimed at determining (self-assessment) or diagnosis (medical psychologist, psychotherapist) negative coping - behaviors that improve it. These methods are aimed at identifying or diagnosing, psychotherapist) negative coping behavior, improve it, meet the methods of science and practical psychotherapeutic correction.

The third stage aims to consolidate the positive effect and prevention: emotional burnout, formation of ineffective models of coping - behavior. At this stage, it is appropriate to use methods of work in the paradigm of psychosynthesis, cognitive-behavioral psychotherapy [12], because according to the literature and personal experience of practical work as a medical psychologist, psychotherapist, author of the program Medical and psychological support of medical college students contribute to the development of innate and the formation of new individual personality traits. During the first week of training, 2 studies were conducted:

Table 1

The program of medical and psychological support of the process of adaptation of medical college students to work in primary positions

\begin{tabular}{|c|c|c|}
\hline Goal & Method & Means \\
\hline \multicolumn{3}{|c|}{ The first stage - Psychodiagnosis } \\
\hline $\begin{array}{l}\text { Formation of motivation to participate in } \\
\text { research, creation of psychotherapeutic } \\
\text { alliance of medical psychologist and } \\
\text { client }\end{array}$ & $\begin{array}{l}\text { Conducting psycho-educational classes to improve } \\
\text { communication between medical psychologist and } \\
\text { client, use of psychotherapeutic tools }\end{array}$ & $\begin{array}{l}\text { Observation, clinical } \\
\text { interview, psychotherapeutic } \\
\text { research }\end{array}$ \\
\hline \multicolumn{3}{|c|}{ The second stage - Medical and psychological correction } \\
\hline $\begin{array}{l}\text { Normalization of psycho-emotional state, } \\
\text { intrapersonal resource, formation of } \\
\text { strategy of social interaction, change of } \\
\text { active life strategy }\end{array}$ & $\begin{array}{l}\text { Leveling the problem of maladaptation by correcting } \\
\text { personality traits, motivational component, developing } \\
\text { skills to work with personal potential, analysis of vital } \\
\text { material using ineffective coping strategies, analysis and } \\
\text { optimization of intrapersonal motivation, optimization } \\
\text { of motivation systems, correction of personal conflicts, } \\
\text { development of psycho-emotional stability }\end{array}$ & $\begin{array}{l}\text { Individual and group social } \\
\text { - psychological training, } \\
\text { consultations. }\end{array}$ \\
\hline \multicolumn{3}{|c|}{ The third stage - Supportive psychocorrection and Psychoprophylaxis } \\
\hline $\begin{array}{c}\text { Consolidation of the positive effect } \\
\text { of work, prevention of recurrence } \\
\text { of manifestations of psychological } \\
\text { maladaptation }\end{array}$ & $\begin{array}{l}\text { Formation of effective models of coping, optimization of } \\
\text { social interaction and system of motivations }\end{array}$ & $\begin{array}{l}\text { Informing, explaining, } \\
\text { developing self-help skills, } \\
\text { supporting regular visits to a } \\
\text { psychologist }\end{array}$ \\
\hline
\end{tabular}


- with the help of the author's questionnaire, the motives for choosing the profession of a medical worker were determined, which allowed to predict the presence of external / internal motivation. The received information gives an understanding in which direction it is necessary to direct correctional work;

- questionnaire LM Sobchyk found the presence of characterological features in relation to the general characteristics of typological personality traits.

100 people were elected to the reference group. The general training helped to identify groups with problems:

1. communicative nature;

2. moral-ethical;

3. volitional nature.

Comparing the results of the observation with the test results, groups for group work and students who needed individual work were formed.

This gradation was caused both by the individual characteristics of the respondents and the nature of the problem.

The author's questionnaire «Means of adaptation of students to study at the medical university of I-III levels of accreditation» was used after the first month of study at the college to obtain information about the reference environment of the respondents.

Our results when comparing the scales of the questionnaire LM Sobchyk and the author's questionnaires gave positive results and were determined by statistical evaluation.

When using the author's questionnaire «Means of adaptation of students to study at a medical university of I-III levels of accreditation» was carried out on the basis of tracking the dynamics of changes in the number of positive answers before and after the experiment, paired, average and general correlation analysis according to the Spearman and Pearson criteria. The results were obtained: the average level of students' adaptation methods increased 2 times.

The results of the questionnaire LM Sobchyk: «Anxiety» changed from 6.8 to 8.6 points. This can be seen as an increase in responsibility, a sense of action. And it can be assessed as a meaningful uncertainty. The lability index changed from 5.4 to 6.2 points. On the scale «Extraversion» we observe an increase in indicators from 5.7 to 6.2 points. «Aggression»: indicators decreased from 6.2 to 4.1 points. Indicators on the scale «Rigidity» changed from 6.7 to 4.8 points. The score on the «introversion» scale turned out to be interesting: it decreased from 4.2 to 3.2. It can be interpreted as shifting the focus of attention from oneself to the environment, including patients. But the scale of «Sensitivity» remained almost unchanged: 7.2-7.1 points. In our opinion, this is a typical feature of the personality of a health worker.

So, speaking about the results obtained before and after the experiments, we can say that we have received positive changes in the personality of students, future health workers. The results of the general correlation analysis according to Spearman's criteria (before the experiment $\mathrm{r}=0.13$, after $-\mathrm{r}=0.17)$ and Pearson $(\mathrm{r}=0.08)$ before and after the experiment coincide. The questionnaire is valid and its results are reliable.

In order to assess the effectiveness of the proposed program of medical and psychological correction of the process of adaptation of medical college students to primary positions, it was proposed to re-test and interview students of experimental and control groups with the help of author questionnaires: «Means of adaptation of students to medical institutions Motives for choosing the profession of a medical worker» and individual - typological questionnaire LM Sobchik. After the introduction of a correctional program to work with students, the average level of student motivation increased by $17 \%$.

In the process of providing psychological assistance and/or support, the students formed a positive attitude to medical and psychological measures as a form of correctional care. A comparative analysis of studies of adaptation of students of higher medical educational institutions to study and further work revealed:

1. Such studies of medical college students have not been conducted by anyone other than the author of the article.

2. Students of medical universities were tested for adaptation to learning. The characteristics and parameters that the researchers were interested in were: emotions, including anxiety, and the correctness of the educational process $[13,14]$.

3. Some foreign scientists took into account the psychological characteristics of the respondents when assessing adaptation [15].

The author of the article did not find a comprehensive study of the problems of adaptation of medical students and the influence of their individual characteristics on the process of adaptation to work.

\section{CONCLUSIONS}

The gradual use of principles and methods of psycho-therapeutic correction in the educational process, group and individual work, leads to the rapid adaptation of students of higher medical educational institutions to work in primary positions through the formation of effective coping behavior. In the process of providing students with psychological assistance / support, they form a positive attitude to medical and psychological measures as a form of correctional care.

\section{REFERENCES}

1. Gordeeva TO. Motivation of the educational activity of schoolchildren and students: structure, mechanisms, conditions for development. Abstract of a dissertation for the degree of Doctor of Psychology. Moscow, 2013. 47 p. [in Russian] 
View at:

Publisher Site: https://www.dissercat.com/content/ motivatsiya-uchebnoi-deyatelnosti-shkolnikov-i-studentov-struktura-mekhanizmy-usloviya-razvi

Science: http://psy-science-council.ru/dissertaions/ detail.php?dissertaion $=2509$

URL: https://docplayer.com/37416495-Gordeeva-tamara-olegovna-motivaciya-uchebnoy-deyatelnosti-shkolnikov-i-studentov-struktura-mehanizmy-usloviya-razvitiya.html

2. Assagioli R. Psychosynthesis. Principles and Techniques. ILI, 2016. 204 p. [in Russian]

View at:

Publisher Site: https://www.yakaboo.ua/psihosintez-principy-i-tehniki.html

Znanium: https://znanium.com/catalog/ document?id=336031

URL: https://gtmarket.ru/library/basis/4317/4318

3. Bakirov A. How to manage yourself and others with the help of NLP. EKSMO, 2014. 416 p. [in Russian] View at:

Publisher Site: https://grenka.ua/4535/Kak-upravlyat-soboy-i-drugimi-s-pomosch-yu-NLP--Kniga-dlyanachinayuschix

URL: https://topreading.ru/book-217687-anvar-bakirov-kak-upravlyat-soboi-i-drugimi-s-pomoshchyu

URL: https://www.rulit.me/books/kak-upravlyatsoboj-i-drugimi-s-pomoshchyu-nlp-read-296996-1. html

4. Tkach R. Fairytale therapy of children's problems. Rech', 2012. 128 p. [in Russian]

View at: Publisher Site: https://www.klex.ru/73b

U R L : ht p s : / / b o o k a . info/book/ tkach_skazkoterapiya_detskih_problem_2008/

5. Hellinger B. Happiness that remains. Where family constellations take us. Moscow: Institute for Consulting and System Solutions, 2011. 160 p. [in Russian] View at:

Publisher Site: http://loveread.ec/view_global. php?id=49146

6. Grishnyaeva OV. Leadership in nursing as a warehouse part of smart adaptation to robotics in drug-prophylactic mortgages. Medical psychology. 2018;3:42-45. [in Ukrainian]

View at: Publisher Site: http://www.mps.kh.ua/ archive $/ 2018 / 3 / 10$

7. Grishnyaeva OV, Antsupova VV, Ostapchuk VG, Ushko IA, Grigoruk VV. Violation of the process of adaptation of junior medical professionals when working in primary positions, as one of the causes of burnout. Current issues of social sciences and history of medicine. Joint Ukrainian-Romanian scientific journal. 2018; 2(18): 119-122. DOI 10.24061/2411-6181.2.2018.45 [in Ukrainian]

View at:

Publisher Site: http://apsnim.bsmu.edu.ua/ home/2_2018 http://apsnim.bsmu.edu.ua/ home/2_2018/gryshnyajeva

URL: https://docs.google.com/view er? $\mathrm{a}=\mathrm{v} \& \mathrm{pid}=$ sites\&srcid=YnNtdS51ZHUudWF8YXBzbmltfGd4OjM0MjI2MmMyZDNkOTlkZmU

8. Antsupova VV, Grishnyaeva OV, Grigoruk VV, Ushko YaA, Ostapchuk VG. Independent work of students of higher medical educational institutions as one of the stages of their further adaptation to work in treatment and prevention institutions. Clinical and experimental pathology. 2017; 16(2): 124-127. DOI: 10.24061/1727-4338.XVI.2.60.2017.25 [in Ukrainian]

View at:

Publisher Site: http://cep.bsmu.edu.ua/article/ view/1727-4338.XVI.2.60.2017.25

9. Grishnyaeva OV, Timoshpolskaya IE Features of disorders of adaptation to the work of junior medical staff during the anti-terrorist operation. Men's health, gender and psychosomatic medicine. 2016; 2:21-26. [in Ukrainian]

View at: Publisher Site: http://ujmh. org $/$ op $=1 \& z=43 \& i=3$

URL: http://ujmh.org/pdf/2_2016/6.pdf

10. Gryshnjaeva OV, Melnychenko OA,Yeryomenko GV, Grigoruk VV, Antsupova VV, Vanina Ya. Motivation as one of the constituent components of the model of the system of medical and psychological support for the process of adaptation of medical college students to work in primary positions. Wiadomosci Lekarskie. 2020; 73(6): 11641168. DOI: 10.36740/ WLek202006116

View at:

Publisher Site: https://wiadlek.pl/06-2020/

URL: https://wiadlek.pl/wp-content/uploads/archive/2020/WLek202006116.pdf

11. ITO test L.N. Sobchik (Individual typological questionnaire / Sobchik Methodology) [in Russian] View at:Publisher Site: https://psycabi.net/ testy/354-test-ito-1-n-sobchik-individualno-tipologicheskij-oprosnik-metodika-sobchik

12. Beck JS. Cognitive Therapy for Complex Cases: What to Do When Simple Solutions Don't Work. Moscow: Dialectics-Williams, 2020. 432 p. [in Russian] View at:

Publisher Site: https://www.yakaboo.ua/kognitivnaja-terapija-dlja-slozhnyh-sluchaev-chto-delat-kogda-prostye-reshenija-ne-rabotajut.html

13. Chizhkova MB. The dynamics of adaptation of firstyear students to the educational environment of a medical university: to the formulation of the problem. Bulletin of the Kemerovo State University. 2019; 21(4): 1039-1049. DOI: 10.21603/2078-8975-201921-4-1039-1049 [in Russian]

View at: Elibrary: https://elibrary.ru/item.asp?id=41591946 
Cyberleninka: https:/cyberleninka.ru/article/n/dinamika-adaptatsii-studentov-pervokursnikov-k-obrazovatelnoy-srede-meditsinskogo-vuza-k-postanovke-problemy

14. Torubarova I.I. Phenomenological method as a way to study the adaptation process of first-year medical university students. Pedagogy. Questions of theory and practice. 2018; 4 (12): 73-77. DOI: 10.30853/ pedagogy.2018.4.16 [in Russian]

View at:

Publisher Site: https://www.gramota.net/materials/4/2018/4/16.html

Cyberleninka: https://cyberleninka.ru/article/n/fenomenologicheskiy-metod-kak-sposob-issledovaniya-pro- tsessa-adaptatsii-studentov-pervokursnikov-meditsinskogo-universiteta

15. Clinciu AI. Adaptation and stress for the first year university students. Procedia-Social and Behavioral Scincse. 2013; 78: 718-722. DOI: 10.1016/j. sbspro.2013.04.382

View at:

Publisher Site: https://www.sciencedirect.com/ science/article/pii/S1877042813009518

Article history Received: 11.08.2021 Revision requested: 29.08.2021 Revision received: 09.12.2021 Accepted: 23.12.2021 Published: 30.12.2021

\title{
ПРОГРАМА МЕДИЧНОГО І ПСИХОЛОГІЧНОГО СУПРОВОДУ ПРОЦЕСУ АДАПТАЦІЇ СТУДЕНТІВ МЕДИЧНОГО КОЛЕДЖУ ДО РОБОТИ НА ПЕРВИННИХ ПОЗИЦІЯХ
}

\author{
Грииняева О.В. \\ Харківський національний медичний університет, Харків, Украӥна \\ elena1969lena1969@gmail.com
}

\begin{abstract}
Актуальність. Сучасний період розвитку України характеризується низкою соціально обумовлених стресових факторів, наслідком яких є значне збільшення кількості випадків короткочасного, а найчастіше - тривалого стресу. Зокрема, психологічний стрес у молодших медсестер (медсестри, фельдшера, акушерки) набагато більший, ніж у лікарів. Це пов>язано з більшою тривалістю вербального та невербального спілкування з пацієнтами та їх родичами. Наслідком цього є професійне виснаження, розвиток психосоматичної патології, зміна місця роботи.
\end{abstract}

Ціль: скласти та запропонувати програму медико-психологічного супроводу процесу адаптації студентів медичного коледжу до основних посад у лікувально-профілактичних закладах.

Методи. В дослідженні приймали участь студенти Харківського обласного медичного коледжу та Дніпровського базового

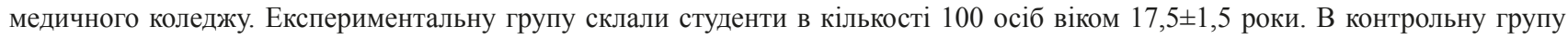
увійшли 45 студентів віком 16,5 $\pm 2,5$ років. Дослідження проводилось без урахування статі. Для оцінки причин дезадаптації використані авторські анкети: «Засоби адаптації студентів до навчання у медичному вузі I-III рівнів акредитації» та індивідуально - типологічний опитувальник Л.М. Собчика. Опитувальник використовувався для визначення достовірності відповідей у категоріях «Брехня» та «Роздратування». Для оцінки запропонованої програми медико-психологічного супроводу процесу адаптації використано статистичні методи: середній та зовнішній кореляційний аналіз за критеріями Спірмана та Пірсона, критерій Стьюдента.

Результати. Досліджена важливість медико-психологічного супроводу процесу адаптації молодших медичних фахівців. Розроблено оригінальну програму, яка представляє собою інтегровану структурно-процесуальну модель адаптації студентів медичного коледжу на основні посади. Після запровадження корекційної програми для роботи зі студентами середній рівень мотивації студентів збільшився на 17\%, що було підтвердженно данними статистичного аналізу до та після проведення експерименту. Середній рівень адаптаційних можливостей студентів збільшився в 2 рази.

Висновки. Програма, що була впроваджена в навчальний процес, дозволить за короткий проміжуток часу пристосувати студентів до роботи на первинних посадах, сформує у них потребу в безперервній освіті і дотриманні принципів здорового способу життя. Дозволить закріпити позитивну копінг стратегію не тільки в робочій обстановці, але й в повсякденному житті.

Ключові слова: медико-психологічна підтримка, адаптація, студенти, основна посада, поведінка для подолання.

\section{ПРОГРАММА МЕДИЦИНСКОГО И ПСИХОЛОГИЧЕСКОГО СОПРОВОЖДЕНИЯ ПРОЦЕССА АДАПТАЦИИ СТУДЕНТОВ МЕДИЦИНСКОГО КОЛЛЕДЖА К РАБОТЕ НА ОСНОВНЫХ МЕСТАХ}

\author{
Гришняева Е.В.
}

Харьковский национальный медицинский университет, Харьков, Украина

elena1969lena1969@gmail.com

Актуальность. Современный период развития Украины характеризуется рядом социально обусловленных стрессовых факторов, следствием которых является значительное увеличение количества случаев кратковременного, а чаще всего - длительного стресса. В частности, психологический стресс у младших медсестер (медсестры, фельдшера, акушерки) намного больше, чем у врачей. Это связано с большею продолжительность вербального и невербального общения с пациентами и их родствен- 
никами. Следствием этого является профессиональное истощение, развитие психосоматической патологии, изменение места работы.

Цель: составить и предложить программу медико-психологического сопровождения процесса адаптации студентов медицинского колледжа к основным должностям в лечебно-профилактических учреждениях.

Методы. В исследовании приняли участие студенты Харьковского областного медицинского колледжа и Днепровского базового медицинского колледжа. Экспериментальную группу составили студенты в количестве 100 человек в возрасте $17,5 \pm 1,5$

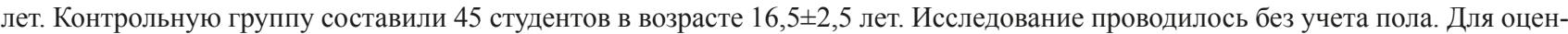
ки причин дезадаптации использовались авторские анкеты: «Средства адаптации студентов к обучению в медицинском вузе I-III уровней аккредитации» и индивидуально-типологический опросник Л.М. Собчик. Опросник использовался для определения достоверности ответов в категориях «Ложь» и «Раздражение». Для оценки предложеной программы медико-психологического сопровождения процесса адаптации использованы статистические методы: средний и внешний корреляционный анализ по критериям Спирмана и Пирсона, критерий Стьюдента.

Результаты. Изучена важность медико-психологического сопровождения процесса адаптации младших медицинских специалистов. Разработана оригинальная программа, представляющая собой интегрированную структурно-процессуальную модель адаптации студентов медицинского колледжа на основные должности. После введения коррекционной программы для работы со студентами, средний уровень мотивации студентов увеличился на $17 \%$, что было подтверждено данными статистического анализа до и после проведения эксперимента. Средний уровень адаптационных возможностей студентов увеличился в 2 раза.

Выводы. Разработанная программа медико-психологического сопровождения позволит за короткий промижуток времени приспособить младших медицинских специалистов к работе на первичных должностях, сформирует потребность в непрерывном образовании и соблюдении принципов здорового образа жизни. Позволит закрепить положительную копинг стратегию не только в рабочей обстановке, но и в повседневной жизни.

Ключевые слова: медико-психологическая поддержка, адаптация, студенты, основная должность, поведение для преодоления. 